\title{
Vitamin D influences asthmatic pathology through its action on diverse immunological pathways
}

*Paul E Pfeffer, *Elizabeth H Mann, Eve Hornsby, Emma S Chambers, Yin-Huai Chen, Louise Rice, and Catherine M Hawrylowicz

${ }^{*}$ denotes equal contribution

Address: MRC and Asthma UK Centre for Allergic Mechanisms in Asthma, King's College London, London SE1 9RT UK

\section{Corresponding author:}

Catherine Hawrylowicz,

Department of Asthma, Allergy and Respiratory Science,

5th Floor Tower Wing,

Guy's Hospital, King's College London,

London SE1 9RT, UK.

Phone: +44 (0) 207188 0598; Fax: +44 (0) 2074038640

catherine.hawrylowicz@kcl.ac.uk

Key words: vitamin D; asthma; immune regulation; glucocorticoids

Running title: Vitamin D: mechanisms in asthma 


\section{Abstract}

The prevalence of vitamin D insufficiency and deficiency has increased markedly in recent decades to current epidemic levels ${ }^{1}$. In parallel there has been an increase in the incidence of a range of immune-mediated conditions ranging from cancer to autoimmune and respiratory diseases, including chronic obstructive pulmonary disease and asthma ${ }^{2,3}$. There is also an association with increased respiratory infections, which are the most common cause of asthma exacerbations ${ }^{3}$. Together, this has resulted in considerable interest in the therapeutic potential of vitamin $\mathrm{D}$ to prevent and improve treatment of asthma and other respiratory diseases. To this end, data from clinical trials involving supplementation with active vitamin $D$, or more commonly a precursor, are starting to emerge. This review considers mechanisms by which vitamin $D$ may act on the immune system to dampen inappropriate inflammatory responses in the airway whilst also promoting tolerance and anti-microbial defence mechanisms that collectively maintain respiratory health.

\section{Asthma}

Heterogeneity in asthma phenotypes (referred to as endotypes) has been described and these endotypes demonstrate differential responsiveness to treatment, underpinned by distinct pathogenic mechanisms ${ }^{4-7}$. Asthma is classically a steroid-sensitive Th2-type immune pathology ${ }^{8}$ and the symptoms of asthma are well-controlled by $\beta 2$-adrenergic agonists and inhaled corticosteroids in the majority of patients. However, these long-term treatments do not 'cure' the disease, and the daily regimen of inhalers and avoidance of asthma triggers has a significant negative impact on many patients' quality of life. Furthermore, there are endotypes of asthma in which corticosteroid treatment is clinically ineffective (steroid insensitive/refractory/resistant asthma) ${ }^{9}$. These steroid-refractory patients suffer considerable morbidity, and are both expensive and challenging to manage clinically.

\section{Vitamin D biology}

Vitamin $D$ is primarily synthesised by ultraviolet-B radiation from sunlight photolysing skin resident 7-dehydrocholesterol into vitamin D3, but it is also be ingested in small amounts through the diet (e.g. in oily fish or dietary supplements). Vitamin D then undergoes step-wise metabolism, first by the enzyme CYP27A1 in the liver into 25-hydroxyvitamin D3 (25(OH)D), the major form of vitamin $\mathrm{D}$ in the body, and then by the mitochondrial enzyme CYP27B1 to the active metabolite $\left(1 \alpha, 25 \text {-dihydroxyvitamin } \mathrm{D} 3\left(1,25(\mathrm{OH})_{2} \mathrm{D} 3\right)\right)^{10}$. Circulating $1,25(\mathrm{OH})_{2} \mathrm{D} 3$ is principally formed by CYP27B1 in the kidney and acts to regulate calcium-phosphate 
homeostasis. However, high levels of local tissue $1,25(\mathrm{OH})_{2} \mathrm{D} 3$ can be produced by CYP27B1, which is also expressed by a diverse range of parenchymal and immunological cell types, including epithelial cells, macrophages and dendritic cells. In vitro studies show these cell

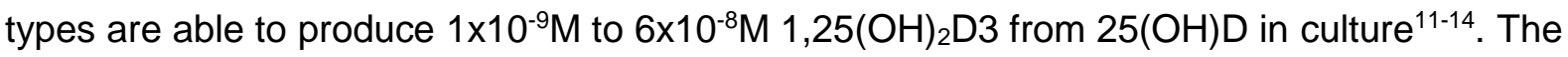
active form of vitamin $\mathrm{D}, 1,25(\mathrm{OH})_{2} \mathrm{D} 3$, principally regulates cellular responses by altering gene transcription - it binds to the vitamin D receptor (VDR), altering the binding of the VDR to genomic vitamin D response elements (VDREs) leading to changes in transcription of VDRE regulated genes. The VDR is expressed by essentially all cells of the immune system and parenchymal cells, particularly upon activation, which enables them to respond to $1,25(\mathrm{OH})_{2} \mathrm{D} 3^{10}$. Furthermore, VDREs are present throughout the genome, including in the promoter regions for many genes associated with autoimmune diseases ${ }^{15}$. The actions of $1,25(\mathrm{OH})_{2} \mathrm{D} 3$ are however limited due to rapid catabolism by CYP24A1, an enzyme that is also expressed by structural and immune cells ${ }^{16}$.

Measurement of circulating $25(\mathrm{OH}) \mathrm{D}$, as the major form of vitamin $\mathrm{D}$ in the body, is used to assess an individual's vitamin $\mathrm{D}$ status. There is an ongoing debate as to what comprises sufficiency, although in general terms serum $25(\mathrm{OH}) \mathrm{D}$ of less than $20 \mathrm{ng} / \mathrm{ml}(50 \mathrm{nmol} / \mathrm{l})$ defines deficiency and $20-30 \mathrm{ng} / \mathrm{ml}(50-75 \mathrm{nmol} / \mathrm{l})$ indicates insufficiency ${ }^{17}$. Factors including genetic diversity, skin colour, obesity, season and lifestyle all influence vitamin $D$ status, but in most populations studied, insufficiency is a problem ${ }^{17}$.

\section{Vitamin D and Asthma - Epidemiological Evidence}

A large study by Black et al. in $2005^{18}$ was one of the first to highlight the positive association between vitamin $\mathrm{D}$ status and pulmonary health. Multiple studies have confirmed this finding, and in particular show that, compared to non-asthmatic controls, the incidence of vitamin $D$ insufficiency is greater amongst paediatric patients ${ }^{19-21}$ and adults ${ }^{22}$ with asthma. Serum $25(\mathrm{OH}) \mathrm{D}$ demonstrates a negative correlation with the severity of asthma (e.g. number of exacerbations) $)^{20,23}$ and the requirement for higher dose corticosteroids ${ }^{22,24,25}$, an effect which is seen most strongly in paediatric cohorts (reviewed in Gupta et al., 2012 ${ }^{26}$ ). Inverse correlations have also been documented between serum 25(OH)D and airway remodeling, $\lg \mathrm{E}$, eosinophil numbers as well as airway hyper responsiveness ${ }^{20,22,25}$ (recently reviewed in Mann et al., 201427). Furthermore, a remarkable number of asthma-associated genes are known to be vitamin $\mathrm{D}$ regulated and polymorphisms within the VDR have been associated with an increased risk of asthma ${ }^{28-31}$.

There are many mechanisms through which vitamin D status may influence asthma and pulmonary health, and which would explain the above epidemiological and genetic 
associations. The discussion in the following sections reveals the diversity of pathways influenced by vitamin D. However asthma itself may influence vitamin D status (reversecausation). Conceptually asthmatics, especially those with pollen sensitivity, may spend a reduced amount of time outside exposed to sunlight, however, limited available evidence does not suggest that this is a significant explanation ${ }^{32}$. Inflammation itself is now known to affect vitamin $\mathrm{D}$ metabolism and a large inflammatory response can cause deterioration in vitamin D status ${ }^{33}$. One of the severe asthma phenotypes is characterised by obesity ${ }^{34}$, which can itself cause decreased circulating vitamin $D$ levels possibly due to sequestration of vitamin $D$ in fat ${ }^{35,36}$. Furthermore corticosteroids, the corner-stone of asthma treatment, affect vitamin $D$ metabolism and in particular increase VDR and CYP24A1 expression ${ }^{37-39}$.

It is most likely that the association between asthma and vitamin $D$ insufficiency is multifactorial, and underpinned by both mechanisms of causation and reverse-causation. The current epidemic of vitamin $D$ insufficiency may predispose the immune system to excessive immunological responses such as seen in asthma, which may in turn cause further worsening of vitamin D status (and in turn further worsening of asthma). Issues of reverse-causation do not mechanistically exclude vitamin $D$ therapies as treatments for asthma in relevant patient groups.

\section{Mechanisms by which vitamin D maintains respiratory health and requlates pulmonary immune responses}

\section{Effects on innate immunity relevant to asthma}

Respiratory tract infections (RTIs) are a major cause of asthma exacerbations ${ }^{40}$, and chronic infection may contribute to the development of severe asthma ${ }^{41}$. Cross sectional, case-control and cohort studies have repeatedly shown an inverse correlation between serum $25(\mathrm{OH}) \mathrm{D}$ and the incidence of acute RTIs ${ }^{42,43}$. There are multiple mechanisms by which vitamin D may enhance anti-microbial responses and beneficially modulate the inflammatory response to bacteria, viruses and fungi ${ }^{44}$ (Figure 1 ).

Pathogen challenge by antigen presenting cells triggers toll-like receptors (TLRs), and TLR stimulation has been shown to enhance CYP27B1 expression in a variety of cell types resulting in increased expression of vitamin D-dependent pathways ${ }^{14,45}$. Many allergens can also stimulate cells through TLRs. In particular, a prominent response to the combination of TLR stimulation and vitamin $D$ in monocytes, macrophages and epithelial cells is the induction of anti-microbial peptides such as cathelcidin and $\beta$-defensin-2. These molecules contribute to host defence through direct anti-microbial activity, as well as by modulating innate and 
adaptive immunity in addition to wound repair. Although the focus of studies regarding antimicrobial peptide actions has been in bacterial infections, they also appear to be important for anti-viral and anti-fungal immunity ${ }^{46,47}$. The enhancement of anti-microbial peptide expression by vitamin $\mathrm{D}$ is accompanied by modulation of the production of pro-inflammatory cytokines which is hypothesised to lead to enhanced pathogen clearance without an excessive inflammatory response ${ }^{48}$. Furthermore, vitamin $D$ stimulates autophagy and autophagosome activity which are important in the anti-microbial response ${ }^{49}$.

\section{Effects on the adaptive immune system}

The primary, but complex, role of vitamin $D$ in dendritic cell (DC) function is modulation of antigen presenting cell function ${ }^{50,51}$. For example, vitamin $\mathrm{D}$ decreases $\mathrm{MHC}$ and costimulatory molecule expression by myeloid $\mathrm{DCs}^{52}$. Since the magnitude and nature of $\mathrm{T}$ cell responses is directly influenced by antigen presenting cells, vitamin D-mediated modulation of DC functions has a major effect on downstream lymphocyte responses. Furthermore, vitamin D has direct effects on T cells, impacting on T cell expansion, phenotype, and cytokine profiles.

Vitamin D consistently inhibits Th1-associated cytokine synthesis in culture and in animal models ${ }^{53}$. However, the effects on Th2 responses relevant to allergic and asthmatic disease are more complex although particularly important because Th2 cytokines play a central role in driving IgE synthesis. Vitamin D has been reported to both inhibit or promote Th2 responses in different animal models and human $\mathrm{T}$ cell culture systems ${ }^{54}$, a significant concern in early studies investigating the potential of vitamin $D$ to improve asthma control. We have reported a non-linear dose effect of $1,25(\mathrm{OH})_{2} \mathrm{D} 3$ in culture on Th2 and Th1 responses ${ }^{55}$ (Figure 2), the relevance of which has become more apparent following epidemiological observations relating lgE levels to serum vitamin D status. Studies by Wjst and colleagues suggested that high levels of vitamin $D$ in early life were associated with an increase in allergic disease at 30years ${ }^{56}$. Subsequently, Hypponen, an author on those earlier studies, demonstrated in a very large cohort that circulating $25(\mathrm{OH}) \mathrm{D}$ levels exhibited a non-linear relationship with serum lgE; elevated $\lg E$ was only observed at very low or high $25(\mathrm{OH}) \mathrm{D}$ levels ${ }^{57}$. We and others, have since reported that serum $25(\mathrm{OH}) \mathrm{D}$ levels negatively correlate with total and aeroallergenspecific $\lg \mathrm{E}^{20,58}$. In vitro, $1,25(\mathrm{OH})_{2} \mathrm{D} 3$ reduces the production of $\lg \mathrm{E}$ from peripheral human $\mathrm{B}$ cells and increases $B$ cell synthesis of the immunoregulatory cytokine IL-10 $0^{59,60}$. Notably IL-10 producing B cells synthesise IgG4, an isotype associated with beneficial outcome following allergen desensitization immunotherapy ${ }^{61}$. Together these data suggest both a non-linear relationship of vitamin $\mathrm{D}$ status with immune parameters associated with allergic and 
asthmatic disease (see model Figure 1), and the existence of compensatory mechanisms to counter vitamin $\mathrm{D}$ enhancement of Th2 responses.

IL-17A, and other Th17-associated cytokines, play a central role in defence against bacterial and fungal mucosal infections. However excessive levels of these cytokines, particularly IL$17 \mathrm{~A}$, is implicated in severe asthma and other immune-mediated diseases. Many patients with severe asthma have a neutrophilic endotype that is associated with increased IL-17A levels/production ${ }^{62-67}$. In addition to triggering neutrophilia, IL-17A promotes airway hyperresponsiveness and remodelling, steroid-resistance, and synthesis of pro-inflammatory cytokines $^{66-69}$. Vitamin D has been shown to reduce IL-17A responses, both in mice and in humans with severe asthma ${ }^{65,70}$.

\section{Effects on regulatory $\mathrm{T}$ lymphocyte responses}

Regulatory T cells (Tregs) are essential to prevent and control inappropriate and excessive, immune responses including those associated with allergy and asthma (reviewed $\mathrm{in}^{71}$ ). However, the frequency and action of Tregs in addition to levels of anti-inflammatory IL-10 are diminished in asthma patients ${ }^{72,73}$. For example, bronchial lavage from severe therapyresistant paediatric asthmatics contains lower levels of IL-10 compared to non-asthmatic subjects, whilst the production of IL-10 by PBMCs/T cells from both paediatric and adult severe asthma patients is reduced ${ }^{74,75}$.

Vitamin $D$ enhances multiple facets of Treg actions ${ }^{76}$ - including promoting distinct CD4+Foxp3+ and CD4+IL-10+ (Tr1/IL-10-Treg) populations in vitro and upregulating expression of the inhibitory costimulatory molecules CTLA-4 and PD1 ${ }^{77-80}$. Interestingly, the nature of the regulatory $T$ cells enhanced by vitamin $D$ is strongly dependent on the concentration of vitamin $D$ and local cytokine milieu; for example varying vitamin $D$ concentrations in different cytokine environments enhance IL-10 expressing Tregs and FoxP3+ Tregs in a mutually exclusive manner ${ }^{79,81}$. In support of these observations, a positive correlation exists between serum 25(OH)D and expression of Foxp3 on peripheral CD4+ T cells, numbers of circulating Foxp3+ T cells as well as levels of IL-10 in the BAL $24,74,82,83$.

In addition to enhancing distinct Treg subsets, vitamin $D$ also affects many other immune regulatory pathways, for example lymphocyte ATP metabolism and CD200 expression. CD200 suppresses the pro-inflammatory activity of local innate immune cells and $1,25(\mathrm{OH})_{2} \mathrm{D} 3$ has been shown to increase expression of CD200 on human peripheral and nasal airway human T cells ${ }^{84}$. ATP is a proinflammatory molecule that can be broken down into immunosuppressive adenosine via the action of 5'-ectonucleotidases CD39 (ATP/ADP into AMP) and CD73 (AMP into adenosine) ${ }^{85}$. Both CD39 and CD73 have been proposed as 
Treg markers and CD39 expression at least is downregulated in severe asthmatics ${ }^{65,86}$. We have shown that in vitro, 1,25(OH)2D3 upregulates CD39 expression and that this contributes to suppression of IL-17A ${ }^{65}$.

\section{Effects on corticosteroid responses}

Early studies from our laboratory investigated immunological actions of glucocorticoids that were relevant to clinical efficacy. We demonstrated that peripheral blood CD4+ $T$ cells from steroid refractory patients were unable to increase secretion of anti-inflammatory IL-10 in vitro when treated with dexamethasone (a synthetic corticosteroid), unlike cells from steroid sensitive individuals and healthy controls ${ }^{75}$. However, vitamin D, either by addition of $1,25(\mathrm{OH})_{2} \mathrm{D} 3$ to cultures or by oral supplementation of the steroid refractory asthmatics themselves for 7 days, restored the dexamethasone induction of IL-10 75 . In addition to directly enhancing IL-10 production, we reported that $1,25(\mathrm{OH})_{2} \mathrm{D} 3$ can overcome downregulation of the glucocorticoid receptor by dexamethasone. This work led directly to a small proof of concept placebo-controlled clinical study demonstrating clinical steroid-enhancing effects of calcitriol in steroid refractory asthma ${ }^{87}$. A steroid-enhancing role for vitamin $D$ in severe asthma is strongly supported by observational studies, particularly in paediatric cohorts ${ }^{25,26}$. In addition to our T cell studies, Zhang et al. ${ }^{88}$ have pioneered studies of the anti-inflammatory and corticosteroid-enhancing actions of vitamin $D$ in monocytes in both steroid refractory and sensitive asthma patients.

We recently reported that dexamethasone upregulates IL-17A from PBMC and CD4+ T cells in vitro, and demonstrated a positive association between inhaled corticosteroid dose (beclomethasone equivalent) and IL-17A synthesis in culture. These data suggest that corticosteroids may contribute to progression in severe asthma by heightening the Th17 responses. Notably, vitamin D strongly inhibited the corticosteroid induced IL-17A in culture ${ }^{65}$.

\section{Effects of vitamin D on airway remodelling}

Airway remodelling in asthma irreversibly reduces lung function, and in general is poorlycontrolled with current therapies ${ }^{89}$. Vitamin $D$ has been shown to reduce airway smooth muscle (ASM) mass, subepithelial deposition and goblet cell hyperplasia ${ }^{90,91}$ (Figure 1). Similarly, an inverse correlation exists between ASM mass and serum 25(OH)D in paediatric asthmatics $^{20}$, whilst addition of vitamin $D$ derivatives to cultures of human ASMs impairs proliferation of cells ${ }^{92}$. Furthermore, vitamin $D$ has been shown to reduce production of 
extracellular matrix proteins from fibroblasts and reduce expression of enzymes implicated in airway remodelling, namely ADAM33 and MMP993-96.

\section{Vitamin D and Fetal Development}

The majority of asthmatic patients develop the disease within the first decade of life, often following on from the development of food allergies and hayfever in the first years of life - the atopic march ${ }^{97}$. This strongly suggests that events in the fetal environment and first months of life have a major effect on whether individuals develop asthma. Lower maternal intake of vitamin $\mathrm{D}$ and maternal vitamin $\mathrm{D}$ deficiency have been found to be associated with increased risk of wheeze/asthma during childhood, both in individual studies and a meta-analysis ${ }^{98-102}$. However some studies show no affect ${ }^{102-105}$ others even an adverse affect ${ }^{106,107}$; disparity in outcomes from clinical studies could be due to a variety of factors summarized in Figure 3. Importantly, maternal vitamin $D$ intake is not equivalent to maternal or fetal vitamin $D$ status as diet is only a minor source of vitamin $D$ and different vitamin $D$ supplements contain very different amounts of vitamin D. Furthermore assessment of the response to vitamin $D$ supplements is complicated by supplements often containing other constituents such as vitamin $A$ that have their own actions on the developing immune system ${ }^{108-110}$. The importance of maternal vitamin $\mathrm{D}$ status is underpinned by the fact that the placenta is a major site for the conversion of $25(\mathrm{OH}) \mathrm{D}_{3}$ to $1,25(\mathrm{OH})_{2} \mathrm{D}_{3}{ }^{111,112}$. In addition to its actions on the developing immune system, vitamin $D$ has an important role in fetal lung development ${ }^{113,114}$.

\section{Clinical Trials of Vitamin D Therapies - Early Evidence}

Given current disagreements as to the definition of vitamin D sufficiency and deficiency, it is not surprising that there is also debate on how to design trials of vitamin $D$ therapies. Different molecular forms of vitamin D may be more or less effective as therapeutic supplements, as well as different dosing regimens. Whether all individuals would benefit from vitamin $D$ supplements or only those with levels below certain thresholds, or only those with certain diseases (and certain endotypes of those diseases) is uncertain. Few studies so far published have investigated vitamin $D$ therapies in asthma and given the uncertainties above, it is not surprising these trials have not reached unanimous conclusions.

In one randomized, double-blind placebo-controlled (RCT) trial 48 children (5-18 years) with newly diagnosed asthma received either budesonide with placebo or budesonide with $500 \mathrm{IU}$ vitamin $D$ daily, a comparatively low dose ${ }^{115}$. The authors observed that vitamin D supplementation in the period from September to July prevented declining serum 
concentrations of $25(\mathrm{OH}) \mathrm{D}$ and reduced the risk of asthma exacerbation triggered by acute respiratory tract infection. In addition to such studies in children, we recently reported in a RCT that $1,25(\mathrm{OH})_{2} \mathrm{D} 3$ led to a modest improvement in the clinical response to oral steroids in a small cohort of adult steroid resistant asthma patients ${ }^{87}$.

The large VIDA trial of vitamin D supplementation in vitamin D insufficient asthmatics recently reported its outcomes ${ }^{105}$ The primary outcome, time to first asthma treatment failure, was not significantly affected by vitamin D supplementation. There was however a trend towards a reduced overall rate of exacerbations in the vitamin $D$ treated group $(P=0.05)$ and significantly greater reduction in inhaled corticosteroid dose. Possible reasons that the primary outcome measure did not show a significant benefit of vitamin D supplementation include the study being underpowered, some vitamin $D$ treated participants not attaining vitamin $D$ sufficiency and that vitamin $\mathrm{D}$ may only be beneficial in particular asthma endotypes.

Data from other large trials in asthma are awaited.

\section{Conclusions and viewpoint}

Evidence from clinical initiatives is starting to emerge, in both asthma and respiratory infections. However the data are likely to be complex and reflect the heterogeneity in trial design. It seems probable based on findings to date, and when placed in the context of experimental data, that beneficial effects are most likely to be observed in individuals who are profoundly vitamin $\mathrm{D}$ deficient. It should however be considered that the body has numerous measures to compensate for low levels of vitamin $D$ intake via mechanisms including parathyroid hormone. Consequently, there may well be a non-linear relationship between intake of vitamin $D$ and its biological effects, an observation that is supported by certain immunological findings.

In summary there are many pathways pertinent to asthma that are strongly influenced by vitamin D. We strongly believe that future trials of vitamin $D$ therapies in asthma need to consider the above issues. In our opinion smaller trials of vitamin $D$ in specific asthma endotypes with asthma-relevant endpoints suggested by clinical science is the way forward.

\section{Figure legend}

\section{Figure 1. The immunomodulatory properties of vitamin $\mathrm{D}$ relevant to asthma}

Vitamin D modulates immune activity in a multitude of ways. Generally a more regulatory environment is promoted by upregulation of Treg numbers and activity, as well as reduced 
pro-inflammatory cytokine production. Clinically the incidence of infections is reduced, airway remodelling halted and corticosteroid responsiveness improved.

Figure 2. Non-linear association of vitamin D levels with immune parameters of relevance to allergic and asthmatic disease.

This cartoon illustrates the non-linear (U-shaped) association of serum 25-hydroxyvitamin D3 levels with IgE; and a non-linear dose effect of 1alpha,25-dihydroxyvitamin D3 in culture on the inhibition of Th2 and enhancement of IL-10 responses ${ }^{55,57}$.

Figure 3. Factors that differ between vitamin D clinical studies and may account for observed differences in results.

Differences in the participant cohort and study design are evident in vitamin D clinical studies and are likely to contribute to variation in the results. Summarised here are the key factors that need to be taken into consideration. 


\section{References}

1. Hypponen E, Power C. Hypovitaminosis D in British adults at age $45 \mathrm{y}$ : nationwide cohort study of dietary and lifestyle predictors. Am J Clin Nutr. 2007;85:860-868.

2. Holick MF. Vitamin D deficiency. N Engl J Med. 2007;357:266-281.

3. Finklea JD, Grossmann RE, Tangpricha V. Vitamin D and chronic lung disease: a review of molecular mechanisms and clinical studies. Adv Nutr. 2011;2(3):244-253.

4. Drazen JM. Asthma: the paradox of heterogeneity. J Allergy Clin Immunol. 2012;129(5):1200-1201.

5. Wenzel SE. Asthma phenotypes: the evolution from clinical to molecular approaches. Nat Med. 2012;18(5):716-725.

6. Woodruff PG, Modrek B, Choy DF, et al. T-helper type 2-driven inflammation defines major subphenotypes of asthma. Am J Respir Crit Care Med. 2009;180(5):388-395.

7. Haldar P, Pavord ID, Shaw DE, et al. Cluster analysis and clinical asthma phenotypes. Am J Respir Crit Care Med. 2008;178(3):218-224.

8. Robinson DS. The role of the T cell in asthma. J Allergy Clin Immunol. 2010;126(6):1081-1091; quiz 1092-1083.

9. Wenzel S. Severe asthma: from characteristics to phenotypes to endotypes. Clin Exp Allergy. 2012;42(5):650-658.

10. Battault S, Whiting SJ, Peltier SL, Sadrin S, Gerber G, Maixent JM. Vitamin D metabolism, functions and needs: from science to health claims. Eur J Nutr. 2013;52(2):429-441.

11. Sigmundsdottir H, Pan J, Debes GF, et al. DCs metabolize sunlight-induced vitamin D3 to 'program' T cell attraction to the epidermal chemokine CCL27. Nat Immunol. 2007;8(3):285-293.

12. Fritsche J, Mondal K, Ehrnsperger A, Andreesen R, Kreutz M. Regulation of 25hydroxyvitamin D3-1 alpha-hydroxylase and production of 1 alpha,25-dihydroxyvitamin D3 by human dendritic cells. Blood. 2003;102(9):3314-3316.

13. Jeffery LE, Wood AM, Qureshi OS, et al. Availability of 25-hydroxyvitamin $D(3)$ to APCs controls the balance between regulatory and inflammatory T cell responses. $J$ Immunol. 2012;189(11):5155-5164.

14. Hansdottir S, Monick MM, Hinde SL, Lovan N, Look DC, Hunninghake GW. Respiratory epithelial cells convert inactive vitamin $D$ to its active form: Potential effects on host defence. J Immunol. 2008;181:7090 - 7099.

15. Ramagopalan SV, Heger A, Berlanga AJ, et al. A ChIP-seq defined genome-wide map of vitamin D receptor binding: associations with disease and evolution. Genome Res. 2010;20(10):1352-1360.

16. Christakos S, Ajibade DV, Dhawan P, Fechner AJ, Mady LJ. Vitamin D: metabolism. Endocrinol Metab Clin North Am. 2010;39(2):243-253, table of contents.

17. Hossein-nezhad A, Holick MF. Vitamin D for health: a global perspective. Mayo Clin Proc. 2013;88(7):720-755.

18. Black PN, Scragg R. Relationship between serum 25-hydroxyvitamin d and pulmonary function in the third national health and nutrition examination survey. Chest. 2005;128(6):3792-3798.

19. Bener A, Ehlayel MS, Tulic MK, Hamid Q. Vitamin D deficiency as a strong predictor of asthma in children. Int Arch Allergy Immunol. 2012;157(2):168-175.

20. Gupta A, Sjoukes A, Richards D, et al. Relationship between Serum Vitamin D, Disease Severity, and Airway Remodeling in Children with Asthma. Am J Respir Crit Care Med. 2011;184(12):1342-1349.

21. Wu AC, Tantisira K, Li L, et al. Effect of vitamin $D$ and inhaled corticosteroid treatment on lung function in children. Am J Respir Crit Care Med. 2012;186(6):508-513.

22. Korn S, Hübner M, Jung M, Blettner M, Buhl R. Severe and uncontrolled adult asthma is associated with vitamin D insufficiency and deficiency. Respir Res. 2013;14(1):25.

23. Brehm JM, Acosta-Pérez E, Klei L, et al. Vitamin D insufficiency and severe asthma exacerbations in Puerto Rican children. Am J Respir Crit Care Med. 2012;186(2):140146. 
24. Majak P, Jerzyńska J, Smejda K, Stelmach I, Timler D, Stelmach W. Correlation of vitamin $D$ with Foxp3 induction and steroid-sparing effect of immunotherapy in asthmatic children. Ann Allergy Asthma Immunol. 2012;109(5):329-335.

25. Goleva E, Searing DA, Jackson LP, Richers BN, Leung DY. Steroid requirements and immune associations with vitamin $D$ are stronger in children than adults with asthma. $J$ Allergy Clin Immunol. 2012;129(5):1243-1251.

26. Gupta A, Bush A, Hawrylowicz C, Saglani S. Vitamin D and asthma in children. Paediatr Respir Rev. 2012;13(4):236-243; quiz 243.

27. Mann EH, Chambers ES, Pfeffer PE, Hawrylowicz CM. Immunoregulatory mechanisms of vitamin D relevant to respiratory health and asthma. Ann N Y Acad Sci. 2014.

28. Raby BA, Lazarus $\mathrm{R}$, Silverman EK, et al. Association of vitamin $\mathrm{D}$ receptor gene polymorphisms with childhood and adult asthma. Am J Respir Crit Care Med. 2004;170(10):1057-1065.

29. Poon $\mathrm{AH}$, Laprise $\mathrm{C}$, Lemire $\mathrm{M}$, et al. Association of vitamin $\mathrm{D}$ receptor genetic variants with susceptibility to asthma and atopy. Am J Respir Crit Care Med. 2004;170(9):967-973.

30. Wjst M, Altmüller J, Faus-Kessler T, Braig C, Bahnweg M, André E. Asthma families show transmission disequilibrium of gene variants in the vitamin D metabolism and signalling pathway. Respir Res. 2006;7:60.

31. Bosse $\mathrm{Y}$, Lemire $\mathrm{M}$, Poon $\mathrm{AH}$, et al. Asthma and genes encoding components of the vitamin D pathway. Respir Res. 2009;10:98.

32. Bose S, Breysse PN, McCormack MC, et al. Outdoor exposure and vitamin D levels in urban children with asthma. Nutr J. 2013;12(1):81.

33. Reid D, Toole BJ, Knox S, et al. The relation between acute changes in the systemic inflammatory response and plasma 25-hydroxyvitamin D concentrations after elective knee arthroplasty. Am J Clin Nutr. 2011;93(5):1006-1011.

34. Juel CT, Ulrik CS. Obesity and asthma: impact on severity, asthma control, and response to therapy. Respir Care. 2013;58(5):867-873.

35. Lagunova Z, Porojnicu AC, Lindberg F, Hexeberg S, Moan J. The dependency of vitamin $D$ status on body mass index, gender, age and season. Anticancer Res. 2009;29(9):3713-3720.

36. Vanlint S. Vitamin D and obesity. Nutrients. 2013;5(3):949-956.

37. Dhawan $\mathrm{P}$, Christakos $\mathrm{S}$. Novel regulation of 25-hydroxyvitamin D3 24-hydroxylase $(24(\mathrm{OH})$ ase) transcription by glucocorticoids: cooperative effects of the glucocorticoid receptor, C/EBP beta, and the Vitamin D receptor in $24(\mathrm{OH})$ ase transcription. $J$ Cell Biochem. 2010;110(6):1314-1323.

38. Akeno N, Matsunuma A, Maeda T, Kawane T, Horiuchi N. Regulation of vitamin D1alpha-hydroxylase and -24-hydroxylase expression by dexamethasone in mouse kidney. J Endocrinol. 2000;164(3):339-348.

39. Hidalgo AA, Deeb KK, Pike JW, Johnson CS, Trump DL. Dexamethasone enhances 1alpha,25-dihydroxyvitamin D3 effects by increasing vitamin $D$ receptor transcription. $J$ Biol Chem. 2011;286(42):36228-36237.

40. Busse WW, Lemanske RF, Gern JE. Role of viral respiratory infections in asthma and asthma exacerbations. Lancet. 2010;376(9743):826-834.

41. Essilfie AT, Simpson JL, Dunkley ML, et al. Combined Haemophilus influenzae respiratory infection and allergic airways disease drives chronic infection and features of neutrophilic asthma. Thorax. 2012;67(7):588-599.

42. Jolliffe DA, Griffiths CJ, Martineau AR. Vitamin D in the prevention of acute respiratory infection: systematic review of clinical studies. J Steroid Biochem Mol Biol. 2013;136:321-329.

43. Bergman P, Lindh AU, Bjorkhem-Bergman L, Lindh JD. Vitamin D and Respiratory Tract Infections: A Systematic Review and Meta-Analysis of Randomized Controlled Trials. Plos One. 2013;8(6). 
44. Khoo AL, Chai L, Koenen H, Joosten I, Netea M, van der Ven A. Translating the role of vitamin D3 in infectious diseases. Crit Rev Microbiol. 2012;38(2):122-135.

45. Liu PT, Stenger S, Li H, et al. Toll-like receptor triggering of a vitamin D mediated human antimicrobial response. Science. 2006;311:1770-1773.

46. Lopez-Garcia B, Lee PH, Yamasaki K, Gallo RL. Anti-fungal activity of cathelicidins and their potential role in Candida albicans skin infection. $J$ Invest Dermatol. 2005;125(1):108-115.

47. Beard JA, Bearden A, Striker R. Vitamin D and the anti-viral state. J Clin Virol. 2011;50(3):194-200.

48. Hansdottir S, Monick MM, Lovan N, Powers L, Gerke A, Hunninghake GW. Vitamin D decreases respiratory syncytial virus induction of NF-kappaB-linked chemokines and cytokines in airway epithelium while maintaining the antiviral state. $\mathrm{J}$ Immunol. 2010;184(2):965-974.

49. Hoyer-Hansen M, Nordbrandt SP, Jaattela M. Autophagy as a basis for the healthpromoting effects of vitamin D. Trends Mol Med. 2010;16(7):295-302.

50. Adorini L, Penna G. Dendritic cell tolerogenicity: a key mechanism in immunomodulation by vitamin $\mathrm{D}$ receptor agonists.

. Hum Immunol. 2009;70(5):345-352.

51. Karthaus N, van Spriel AB, Looman MW, et al. Vitamin D controls murine and human plasmacytoid dendritic cell function. J Invest Dermatol. 2014;134(5):1255-1264.

52. Penna G, Amuchastegui S, Giarratana N, et al. 1,25-Dihydroxyvitamin D3 selectively modulates tolerogenic properties in myeloid but not plasmacytoid dendritic cells. $J$ Immunol. 2007;178:145-153.

53. Cantorna MT. Mechanisms underlying the effect of vitamin D on the immune system. Proc Nutr Soc. 2010;69(3):286-289.

54. Lange NE, Litonjua A, Hawrylowicz CM, Weiss S. Vitamin D, the immune system and asthma. Expert Rev Clin Immunol. 2009;5(6):693-702.

55. Urry Z, Xystrakis E, Richards DF, et al. Ligation of TLR9 induced on human IL-10secreting Tregs by 1alpha,25-dihydroxyvitamin D3 abrogates regulatory function. $J$ Clin Invest. 2009;119(2):387-398.

56. Hypponen E, Sovio U, Wjst M, et al. Infant vitamin d supplementation and allergic conditions in adulthood: northern Finland birth cohort 1966. Ann N Y Acad Sci. 2004;1037:84-95.

57. Hyppönen E, Berry DJ, Wjst M, Power C. Serum 25-hydroxyvitamin D and IgE - a significant but nonlinear relationship. Allergy. 2009;64(4):613-620.

58. Sharief S, Jariwala S, Kumar J, Muntner P, Melamed ML. Vitamin D levels and food and environmental allergies in the United States: results from the National Health and Nutrition Examination Survey 2005-2006. J Allergy Clin Immunol. 2011;127(5):11951202.

59. Heine G, Niesner U, Chang HD, et al. 1,25-dihydroxyvitamin D(3) promotes IL-10 production in human B cells. Eur J Immunol. 2008;38(8):2210-2218.

60. Hartmann B, Heine $G$, Babina $M$, et al. Targeting the vitamin $D$ receptor inhibits the $B$ cell-dependent allergic immune response. Allergy. 2011;66(4):540-548.

61. van de Veen W, Stanic B, Yaman G, et al. IgG4 production is confined to human IL-10producing regulatory $B$ cells that suppress antigen-specific immune responses. $J$ Allergy Clin Immunol. 2013;131(2):1204 -1212.

62. Chakir J, Shannon J, Molet S, et al. Airway remodeling-associated mediators in moderate to severe asthma: effect of steroids on TGF-beta, IL-11, IL-17, and type I and type III collagen expression. J Allergy Clin Immunol. 2003;111(6):1293-1298.

63. Agache I, Ciobanu C, Agache C, Anghel M. Increased serum IL-17 is an independent risk factor for severe asthma. Respir Med. 2010;104(8):1131-1137.

64. Vazquez-Tello A, Halwani R, Hamid Q, Al-Muhsen S. Glucocorticoid Receptor-Beta Up-Regulation and Steroid Resistance Induction by IL-17 and IL-23 Cytokine Stimulation in Peripheral Mononuclear Cells. J Clin Immunol. 2012. 
65. Nanzer AM, Chambers ES, Ryanna K, et al. Enhanced production of IL-17A in patients with severe asthma is inhibited by 1a,25-dihydroxyvitamin D3 in a glucocorticoidindependent fashion. J Allergy Clin Immunol. 2013.

66. Zhao J, Lloyd CM, Noble A. Th17 responses in chronic allergic airway inflammation abrogate regulatory $\mathrm{T}$-cell-mediated tolerance and contribute to airway remodeling. Mucosal Immunol. 2013;6(2):335-346.

67. McKinley L, Alcorn JF, Peterson A, et al. TH17 cells mediate steroid-resistant airway inflammation and airway hyperresponsiveness in mice. J Immunol. 2008;181(6):40894097.

68. Zijlstra GJ, Ten Hacken NH, Hoffmann RF, van Oosterhout AJ, Heijink IH. Interleukin17A induces glucocorticoid insensitivity in human bronchial epithelial cells. Eur Respir J. 2012 39(2):439-445.

69. Wilson RH, Whitehead GS, Nakano H, Free ME, Kolls JK, Cook DN. Allergic sensitization through the airway primes Th17-dependent neutrophilia and airway hyperresponsiveness. Am J Respir Crit Care Med. 2009;180(8):720-730.

70. Palmer MT, Lee YK, Maynard CL, et al. Lineage-specific effects of 1,25dihydroxyvitamin $\mathrm{D}(3)$ on the development of effector CD4 T cells. J Biol Chem. 2011;286(2):997-1004.

71. Lloyd CM, Hawrylowicz CM. Regulatory T cells in asthma. Immunity. 2009;31(3):438449.

72. Hawrylowicz CM, O'Garra A. Potential role of interleukin-10-secreting regulatory $T$ cells in allergy and asthma. Nat Rev Immunol. 2005;5(4):271-283.

73. Hartl D, Koller B, Mehlhorn AT, et al. Quantitative and functional impairment of pulmonary CD4+CD25hi regulatory T cells in pediatric asthma. J Allergy Clin Immunol. 2007;119(5):1258-1266.

74. Gupta A, Dimeloe S, Richards DF, et al. Defective IL-10 expression and in vitro steroid-induced IL-17A in paediatric severe therapy-resistant asthma. Thorax. 2013.

75. Xystrakis E, Kusumakar S, Boswell S, et al. Reversing the defective induction of IL-10secreting regulatory $T$ cells in glucocorticoid-resistant asthma patients. J Clin Invest. 2006;116(1):146-155.

76. Chambers ES, Hawrylowicz CM. The impact of vitamin D on regulatory T cells. Curr Allergy Asthma Rep. 2011;11(1):29-36.

77. Penna G, Roncari A, Amuchastegui S, et al. Expression of the inhibitory receptor ILT3 on dendritic cells is dispensable for induction of CD4+Foxp3+ regulatory $T$ cells by 1,25-dihydroxyvitamin D3. Blood. 2005;106(10):3490-3497.

78. Jeffery LE, Burke F, Mura M, et al. 1,25-Dihydroxyvitamin D3 and IL-2 combine to inhibit T cell production of inflammatory cytokines and promote development of regulatory T cells expressing CTLA-4 and FoxP3. J Immunol. 2009;183(9):5458-5467.

79. Urry Z, Chambers ES, Xystrakis E, et al. The role of 1 $\alpha, 25$-dihydroxyvitamin D3 and cytokines in the promotion of distinct Foxp3+ and IL-10+ CD4+ T cells. Eur J Immunol. 2012;42(10):2697-2708.

80. Kang SW, Kim SH, Lee N, et al. 1,25-Dihyroxyvitamin D3 promotes FOXP3 expression via binding to vitamin $\mathrm{D}$ response elements in its conserved noncoding sequence region. J Immunol. 2012;188(11):5276-5282.

81. Chambers ES, Suwannasaen D, Mann EH, et al. 1alpha,25-dihydroxyvitaminD3 in combination with TGF $\beta$ increases the frequency of Foxp3+ Tregs through preferential expansion and usage of IL-2. Immunology. 2014.

82. Maalmi $\mathrm{H}$, Berraïes A, Tangour $\mathrm{E}$, et al. The impact of vitamin $\mathrm{D}$ deficiency on immune T cells in asthmatic children: a case-control study. J Asthma Allergy. 2012;5:11-19.

83. Chambers ES, Nanzer AM, Richards DF, et al. Serum 25-dihydroxyvitamin D levels correlate with CD4(+)Foxp3(+) T-cell numbers in moderate/severe asthma. J Allergy Clin Immunol. 2012;130(2):542-544.

84. Dimeloe S, Richards DF, Urry ZL, et al. 1a,25-dihydroxyvitamin D3 promotes CD200 expression by human peripheral and airway-resident T cells. Thorax. 2012;67(7):574581. 
85. Regateiro FS, Cobbold SP, Waldmann H. CD73 and adenosine generation in the creation of regulatory microenvironments. Clin Exp Immunol. 2013;171(1):1-7.

86. Deaglio S, Dwyer KM, Gao W, et al. Adenosine generation catalyzed by CD39 and CD73 expressed on regulatory T cells mediates immune suppression. J Exp Med. 2007;204(6):1257-1265.

87. Nanzer AM, Chambers ES, Ryanna K, et al. The effects of calcitriol treatment in glucocorticoid-resistant asthma. J Allergy Clin Immunol. 2014.

88. Zhang Y, Leung DY, Goleva E. Anti-inflammatory and corticosteroid-enhancing actions of vitamin $D$ in monocytes of patients with steroid-resistant and those with steroidsensitive asthma. J Allergy Clin Immunol. 2014.

89. Durrani SR, Viswanathan RK, Busse WW. What effect does asthma treatment have on airway remodeling? Current perspectives. J Allergy Clin Immunol. 2011;128(3):439448; quiz 449-450.

90. Lai G, Wu C, Hong J, Song Y. Dihydroxyvitamin $\mathrm{D}(3)(1,25-(\mathrm{OH})(2) \mathrm{D}(3))$ attenuates airway remodeling in a murine model of chronic asthma. $J$ Asthma. 2013;50:133-140.

91. Banerjee A, Panettieri R, Jr. Vitamin D modulates airway smooth muscle function in COPD. Curr Opin Pharmacol. 2012;12(3):266-274.

92. Damera G, Fogle HW, Lim P, et al. Vitamin D inhibits growth of human airway smooth muscle cells through growth factor-induced phosphorylation of retinoblastoma protein and checkpoint kinase 1. Br J Pharmacol. 2009;158(6):1429-1441.

93. Song Y, Qi H, Wu C. Effect of 1,25- $(\mathrm{OH}) 2 \mathrm{D} 3$ (a vitamin $D$ analogue) on passively sensitized human airway smooth muscle cells. Respirology. 2007;12(4):486-494.

94. Foley SC, Mogas AK, Olivenstein R, et al. Increased expression of ADAM33 and ADAM8 with disease progression in asthma. J Allergy Clin Immunol. 2007;119(4):863871.

95. Slominski AT, Li W, Bhattacharya SK, et al. Vitamin D analogs $17,20 \mathrm{~S}(\mathrm{OH}) 2 \mathrm{pD}$ and $17,20 \mathrm{R}(\mathrm{OH}) 2 \mathrm{pD}$ are noncalcemic and exhibit antifibrotic activity. J Invest Dermatol. 2011;131(5):1167-1169.

96. Johnson LA, Sauder KL, Rodansky ES, Simpson RU, Higgins PD. CARD-024, a vitamin $D$ analog, attenuates the pro-fibrotic response to substrate stiffness in colonic myofibroblasts. Exp Mol Pathol. 2012;93(1):91-98.

97. Yunginger JW, Reed CE, O'Connell EJ, Melton LJr, O'Fallon WM, Silverstein MD. A community-based study of the epidemiology of asthma. Incidence rates, 1964-1983. Am Rev Respir Dis. 1992;146(4):888-894.

98. Camargo CA, Rifas-Shiman SL, Litonjua AA, et al. Maternal intake of vitamin D during pregnancy and risk of recurrent wheeze in children at $3 \mathrm{y}$ of age. Am J Clin Nutr. 2007;85(3):788-795.

99. Devereux G, Litonjua AA, Turner SW, et al. Maternal vitamin D intake during pregnancy and early childhood wheezing. Am J Clin Nutr. 2007;85(3):853-859.

100. Miyake $Y$, Sasaki S, Tanaka K, Hirota Y. Dairy food, calcium and vitamin D intake in pregnancy, and wheeze and eczema in infants. Eur Respir J. 2010;35(6):1228-1234.

101. Nurmatov U, Devereux G, Sheikh A. Nutrients and foods for the primary prevention of asthma and allergy: systematic review and meta-analysis. J Allergy Clin Immunol. 2011;127(3):724-733.e721-730.

102. Camargo CA, Ingham T, Wickens $K$, et al. Cord-blood 25-hydroxyvitamin D levels and risk of respiratory infection, wheezing, and asthma. Pediatrics. 2011;127(1):e180-187.

103. Goldring ST, Griffiths CJ, Martineau AR, et al. Prenatal vitamin d supplementation and child respiratory health: a randomised controlled trial. PLoS One. 2013;8(6):e66627.

104. Chawes BL, Bønnelykke K, Jensen PF, Schoos AM, Heickendorff L, Bisgaard H. Cord Blood 25(OH)-Vitamin D Deficiency and Childhood Asthma, Allergy and Eczema: The COPSAC2000 Birth Cohort Study. PLoS One. 2014;9(6):e99856.

105. Castro M, King TS, Kunselman SJ, et al. Effect of vitamin D3 on asthma treatment failures in adults with symptomatic asthma and lower vitamin D levels: the VIDA randomized clinical trial. JAMA. 2014;311(20):2083-2091. 
106. Gale CR, Robinson SM, Harvey NC, et al. Maternal vitamin D status during pregnancy and child outcomes. Eur J Clin Nutr. 2008;62(1):68-77.

107. Erkkola M, Kaila M, Nwaru BI, et al. Maternal vitamin D intake during pregnancy is inversely associated with asthma and allergic rhinitis in 5-year-old children. Clin Exp Allergy. 2009;39(6):875-882.

108. Mai XM, Langhammer A, Chen Y, Camargo CA. Cod liver oil intake and incidence of asthma in Norwegian adults--the HUNT study. Thorax. 2013;68(1):25-30.

109. Rajakumar K. Vitamin D, cod-liver oil, sunlight, and rickets: a historical perspective. Pediatrics. 2003;112(2):e132-135.

110. Linday LA, Umhau JC, Shindledecker RD, Dolitsky JN, Holick MF. Cod liver oil, the ratio of vitamins $A$ and $D$, frequent respiratory tract infections, and vitamin $D$ deficiency in young children in the United States. Ann Otol Rhinol Laryngol. 2010;119(1):64-70.

111. Gray TK, Lester GE, Lorenc RS. Evidence for extra-renal 1 alpha-hydroxylation of 25hydroxyvitamin D3 in pregnancy. Science. 1979;204(4399):1311-1313.

112. Weisman Y, Harell A, Edelstein S, David M, Spirer Z, Golander A. 1 alpha, 25Dihydroxyvitamin D3 and 24,25-dihydroxyvitamin D3 in vitro synthesis by human decidua and placenta. Nature. 1979;281(5729):317-319.

113. Kho AT, Sharma S, Qiu W, et al. Vitamin D related genes in lung development and asthma pathogenesis. BMC Med Genomics. 2013;6:47.

114. Zosky GR, Hart PH, Whitehouse AJ, et al. Vitamin D Deficiency at 16-20 Weeks Gestation Is Associated with Impaired Lung Function and Asthma at 6 Years of Age. Ann Am Thorac Soc. 2014.

115. Majak P, Olszowiec-Chlebna M, Smejda K, Stelmach I. Vitamin D supplementation in children may prevent asthma exacerbation triggered by acute respiratory infection. $J$ Allergy Clin Immunol. 2011;127(5):1294-1296. 